\title{
Effects of Morinda citrifolia Leaf Extract on Glucose Absorption through Intestinal Epithelial Membrane in Wistar Rat Models
}

\author{
Rikho Melga Shalim, ${ }^{1}$ Mas Rizky A. Adipurna Syamsunarno, ${ }^{2}$ Muhammad Nurhalim Shahib ${ }^{2}$ \\ ${ }^{1}$ Faculty of Medicine Universitas Padjadjaran, \\ ${ }^{2}$ Department of Biochemistry and Molecular Biology Faculty of Medicine Universitas Padjadjaran
}

\begin{abstract}
Background: Noni fruit (Morinda citrifolia) has been used as herbal medicine by Indonesian people. However, the effect of noni leaves as an antihyperglycemic agent is still unknown. This study was conducted to find out the effect of Morinda citrifolia leaves on glucose absorption through intestinal epithelial membrane in wistar rat models.

Methods: The study was conducted in November 2015 at the Biochemistry and Molecular Biology Laboratory Faculty of Medicine, Universitas Padjadjaran. We used in situ perfusion and rats were divided into 2 groups. The first group used glucose solution as a control. The second group used glucose with extracts. Specimens were taken before and after perfusion to check the amount of glucose with spectrophotometer. Statistical analysis using t-test was conducted to compare the total absorbed concentration of glucose from each group. Results: From calculation we found the kinetic value $(\mathrm{Km})$ of glucose absorption without extract $(\mathrm{Km}=17.24)$ and with extract $(\mathrm{Km}=16.67)$. Statistical test showed there was no significant in results $(\mathrm{p}>0.05)$.

Conclusions: There is no effect of Morinda citrifolia leaf extract on glucose absorption. However, kinetics of glucose absorption suggested a non-competitive inhibition by Morinda citrifolia leaf extract.
\end{abstract}

Keywords: Antihyperglycemic, glucose absorption, herbal, Morinda citrifolia, transport kinetics

\section{Introduction}

Herbal medicine is a common term for people in Indonesia. Indonesian people use it for therapy purposes such as heart disease, neuronal problems, and cancer. Studies from around the world also succeed to prove the effect of herb. ${ }^{1,2}$ One of the herbs that is commonly used is Noni (Morinda citrifolia). It is a plant that grows well in Indonesia. This plant has many therapeutical effects to be used in medicating diseases. ${ }^{3}$ However, for years, the use of Noni is more likely from its fruit rather than the other part of it, the leaves. Noni leaves contain alkaloids, saponins, tannins, flavonoids, steroids, glycosides, and ascorbic acids. ${ }^{4}$ Some of them known to have effects to inhibit glucose transport in small intestine.$^{5,6}$

A study was conducted and proved that saponins and flavonoids have effects in glucose transport. ${ }^{7}$ Nevertheless, the mechanism of how these chemical substances work is yet to be known. In 2010, the World Health Organization (WHO) found 10\% of Indonesian people have hyperglycemic condition. ${ }^{8}$ It is a condition when blood glucose is above the normal range. This condition may cause complications that could endanger the person who bears it. Blood glucose rises because of some mechanisms including glucose transport in the small intestine. With intervention to this process, there is a possibility to overcome the hyperglycemic condition. Concentration of glucose that will be absorbed is also a decisive factor in glucose absorption. Therefore, the kinetics of glucose absorption is related to this study.

Furthermore, kinetics of glucose absorption can be determined using a Lineweaver-Burk graph. By use of a millimeter block paper and scale of axis and ordinate, the researcher can calculate the kinetics value or MichaelisMenten constant (Km). The value of Km reflects the type of inhibition from the extract. ${ }^{9}$ The purpose of this study was to find the effects of Morinda citrifolia leaves on glucose absorption through intestine and the kinetics of glucose transport in the small intestine of wistar rat.

Correspondence: Rikho Melga Shalim, Faculty of Medicine, Universitas Padjadjaran, Jalan Raya Bandung-Sumedang Km.21, Jatinangor, Sumedang, Indonesia, Email: melgaz22_7@ymail.com 


\section{Methods}

This study was conducted in November 2015 at the Biochemistry and Molecular Biology Laboratory, Faculty of Medicine Universitas Padjadjaran, Jatinangor. Morinda citrifolia leaves were purchased and extracted with ethanol at the Pharmacy Laboratory of Institut Teknologi Bandung (ITB). The leaves were picked from the middle part of the tree which was 2-3 years old and grown in Coblong, Bandung. Briefly, they were cut into small pieces and put in the heating and drying oven. Then, the dried leaves were mixed with ethanol $70 \%$ to undergo the maceration process.

Twelve rats aged twelve to sixteen weeks old wistar rats with body weight between 200 and 250 grams were adapted for 7 days before experiment. The Health Research Ethics Committee Faculty of Medicine, Universitas Padjadjaran has agreed and gave permission to conduct this study with concern to the ethical aspects such as 3R and use of the resource equation method to calculate the number of sample needed. ${ }^{10,11}$

There were conditions to be met before the rats were going to the experiment. These conditions were the inclusion and exclusion criteria. The rats must be in healthy conditions without wounds, and active. There were also some conditions that excluded the rats to be used further such as a dropped in weight more than $10 \%$ after the adaptation period and if the rats had been used in an experiment before.

The glucose absorption was measured by in situ perfusion technique to make sure every rat in each group was given the same amount of glucose. Then, the rats were fasted and anesthetized by Ketamine with dosage of $0.13 \mathrm{mg} / 100$ gram body weight. After the anesthesia has worked, the abdomen was opened to install cannulas at $10 \mathrm{~cm}$ after pylorus and $25 \mathrm{~cm}$ from the first cannula with a marked string to help measure the length of intestine. Next step, each cannula was connected with a rubber tube to bath the intestine with solutions.

Furthermore, the rats were divided into 2 groups. The first group was the control group which was given glucose solution, while the second group was given glucose with Morinda citrifolia leaf extract solution. The intestine was perfused with $2.5,5$, and $10 \mathrm{mmol}$ for every 15 minutes with and without leaf extract. Pre and post perfused solution were collected at the end of perfusion process.

The solutions were mixed with aquadest and trichloroacetic acid (TCA) 8\% and centrifuged for 10 minutes at $3000 \mathrm{rpm}$. To obtain the best result, the solutions were incubated in $37^{\circ} \mathrm{C}$ for 10 minutes or at room temperature for 25

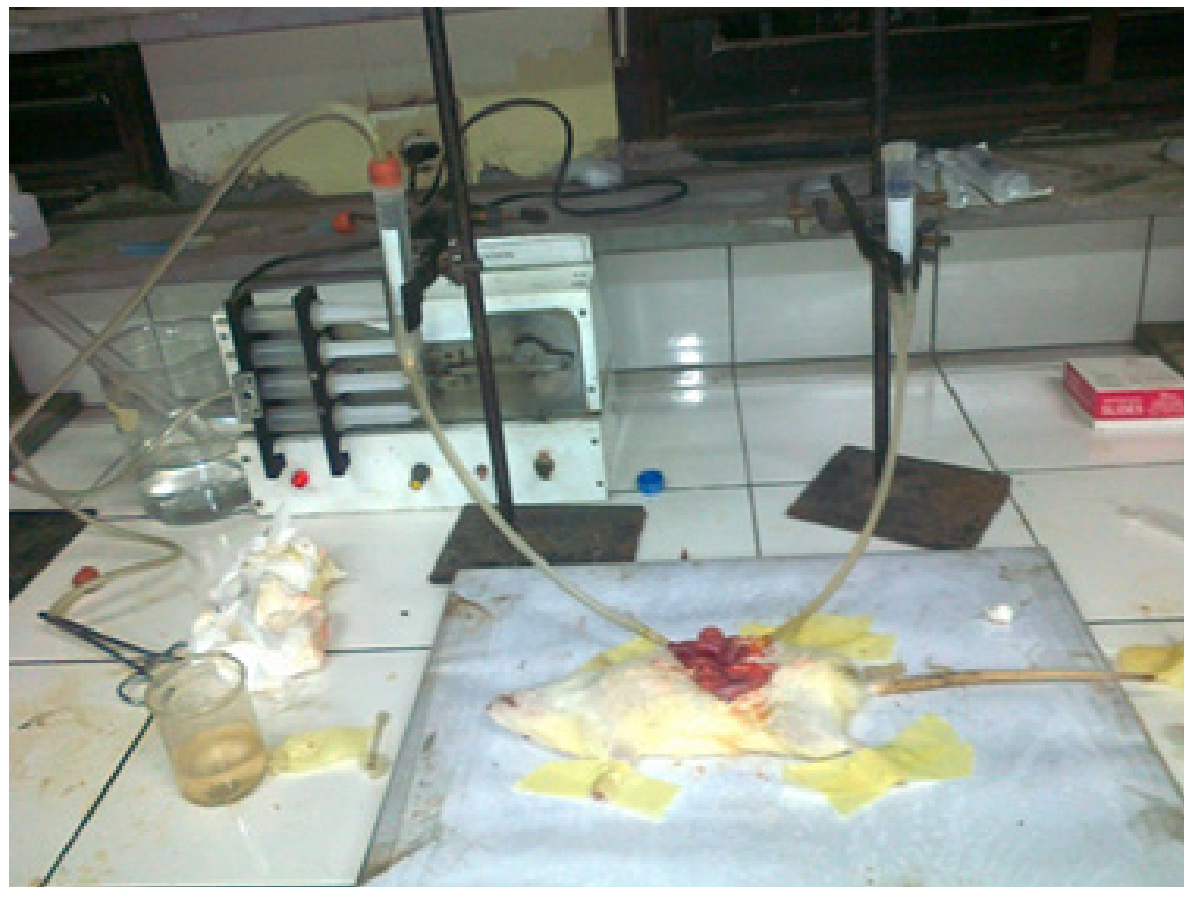

Figure 1 Rat with Perfusion Set 
Table 1 Absorption Data of Control Group

\begin{tabular}{|c|c|c|c|c|c|c|}
\hline Solution & Rat & Time & Absorbancy & $\begin{array}{c}\text { Remaining } \\
\text { Glucose }(\mathrm{mg} / \mathrm{dL})\end{array}$ & $\begin{array}{c}\text { Absorbed } \\
\text { Glucose }(\mathrm{mg} / \mathrm{dL})\end{array}$ & $\begin{array}{c}\text { Mean } \pm \text { Standard } \\
\text { Deviation }\end{array}$ \\
\hline \multirow[t]{12}{*}{ G1 } & \multirow[t]{2}{*}{1} & Before & 0.045 & 35.71 & \multirow{2}{*}{4.76} & \multirow[t]{12}{*}{$11.11 \pm 4.788$} \\
\hline & & After & 0.039 & 30.95 & & \\
\hline & \multirow[t]{2}{*}{2} & Before & 0.043 & 34.13 & \multirow{2}{*}{14.29} & \\
\hline & & After & 0.025 & 19.84 & & \\
\hline & \multirow[t]{2}{*}{3} & Before & 0.044 & 34.92 & \multirow{2}{*}{17.46} & \\
\hline & & After & 0.022 & 17.46 & & \\
\hline & \multirow[t]{2}{*}{4} & Before & 0.044 & 34.92 & \multirow{2}{*}{7.14} & \\
\hline & & After & 0.035 & 27.78 & & \\
\hline & \multirow[t]{2}{*}{5} & Before & 0.045 & 35.71 & \multirow{2}{*}{9.52} & \\
\hline & & After & 0.033 & 26.19 & & \\
\hline & \multirow[t]{2}{*}{6} & Before & 0.039 & 30.95 & \multirow{2}{*}{13.49} & \\
\hline & & After & 0.022 & 17.46 & & \\
\hline \multirow[t]{12}{*}{ G2 } & \multirow[t]{2}{*}{1} & Before & 0.130 & 103.17 & \multirow{2}{*}{46.83} & \multirow[t]{12}{*}{$36.77 \pm 9.585$} \\
\hline & & After & 0.071 & 56.35 & & \\
\hline & \multirow[t]{2}{*}{2} & Before & 0.134 & 106.35 & \multirow{2}{*}{44.44} & \\
\hline & & After & 0.078 & 61.90 & & \\
\hline & \multirow[t]{2}{*}{3} & Before & 0.133 & 105.56 & \multirow{2}{*}{44.44} & \\
\hline & & After & 0.077 & 61.11 & & \\
\hline & \multirow[t]{2}{*}{4} & Before & 0.131 & 103.97 & \multirow{2}{*}{24.60} & \\
\hline & & After & 0.100 & 79.37 & & \\
\hline & \multirow[t]{2}{*}{5} & Before & 0.134 & 106.35 & \multirow{2}{*}{28.57} & \\
\hline & & After & 0.098 & 77.78 & & \\
\hline & \multirow[t]{2}{*}{6} & Before & 0.131 & 103.97 & 217 & \\
\hline & & After & 0.091 & 72.22 & 31.15 & \\
\hline G3 & 1 & Before & 0.254 & 201.59 & 5704 & $56.08 \pm 8.364$ \\
\hline & & After & 0.181 & 143.65 & 31.94 & \\
\hline & 2 & Before & 0.254 & 201.59 & 6429 & \\
\hline & & After & 0.173 & 137.30 & 04.27 & \\
\hline & 3 & Before & 0.257 & 203.97 & 6507 & \\
\hline & & After & 0.174 & 138.10 & ו & \\
\hline & 4 & Before & 0.239 & 189.68 & 1265 & \\
\hline & & After & 0.184 & 146.03 & 40.00 & \\
\hline & 5 & Before & 0.240 & 190.48 & F 17 & \\
\hline & & After & 0.173 & 137.30 & J3.17 & \\
\hline & 6 & Before & 0.241 & 191.27 & 5150 & \\
\hline & & After & 0.176 & 139.68 & צ1.J & \\
\hline
\end{tabular}


Rikho Melga Shalim, Mas Rizky Anggun Adipurna Syamsunarno, Muhammad Nurhalim Shahib: Effects of Morinda 549 citrifolia Leaf Extract on Glucose Absorption through Intestinal Epithelial Membrane in Wistar Rat Models

Table 2 Absorption Data of Experimental Group

\begin{tabular}{|c|c|c|c|c|c|c|}
\hline Solution & Rat & Time & Absorbancy & $\begin{array}{c}\text { Remaining } \\
\text { Glucose (mg/dL) }\end{array}$ & $\begin{array}{c}\text { Absorbed } \\
\text { Glucose }(\mathrm{mg} / \mathrm{dL})\end{array}$ & $\begin{array}{c}\text { Mean } \pm \text { Standard } \\
\text { Deviation }\end{array}$ \\
\hline \multirow[t]{12}{*}{ M1 } & \multirow[t]{2}{*}{1} & Before & 0.045 & 35.71 & \multirow{2}{*}{17.46} & $14.02 \pm 4.935$ \\
\hline & & After & 0.023 & 18.25 & & \\
\hline & \multirow[t]{2}{*}{2} & Before & 0.047 & 37.30 & \multirow{2}{*}{22.22} & \\
\hline & & After & 0.019 & 15.08 & & \\
\hline & \multirow[t]{2}{*}{3} & Before & 0.046 & 36.51 & \multirow{2}{*}{11.90} & \\
\hline & & After & 0.031 & 24.60 & & \\
\hline & \multirow[t]{2}{*}{4} & Before & 0.046 & 36.51 & \multirow{2}{*}{12.70} & \\
\hline & & After & 0.030 & 23.81 & & \\
\hline & \multirow[t]{2}{*}{5} & Before & 0.041 & 32.54 & \multirow{2}{*}{11.11} & \\
\hline & & After & 0.027 & 21.43 & & \\
\hline & \multirow[t]{2}{*}{6} & Before & 0.037 & 29.37 & \multirow{2}{*}{8.73} & \\
\hline & & After & 0.026 & 20.63 & & \\
\hline \multirow[t]{12}{*}{ M2 } & \multirow[t]{2}{*}{1} & Before & 0.089 & 70.63 & \multirow{2}{*}{42.06} & $21.83 \pm 17.072$ \\
\hline & & After & 0.036 & 28.57 & & \\
\hline & \multirow[t]{2}{*}{2} & Before & 0.092 & 73.02 & \multirow{2}{*}{43.65} & \\
\hline & & After & 0.037 & 29.37 & & \\
\hline & \multirow[t]{2}{*}{3} & Before & 0.094 & 74.60 & \multirow{2}{*}{19.05} & \\
\hline & & After & 0.070 & 55.56 & & \\
\hline & \multirow[t]{2}{*}{4} & Before & 0.109 & 86.51 & \multirow{2}{*}{10.32} & \\
\hline & & After & 0.096 & 76.19 & & \\
\hline & \multirow[t]{2}{*}{5} & Before & 0.092 & 73.02 & \multirow{2}{*}{12.70} & \\
\hline & & After & 0.076 & 60.32 & & \\
\hline & \multirow[t]{2}{*}{6} & Before & 0.094 & 74.60 & \multirow{2}{*}{3.17} & \\
\hline & & After & 0.090 & 71.43 & & \\
\hline \multirow[t]{12}{*}{ M3 } & 1 & Before & 0.219 & 173.81 & 6190 & $51.85 \pm 9.546$ \\
\hline & & After & 0.141 & 111.90 & 01.90 & \\
\hline & 2 & Before & 0.221 & 175.40 & 6587 & \\
\hline & & After & 0.138 & 109.52 & 8.07 & \\
\hline & 3 & Before & 0.233 & 184.92 & 4683 & \\
\hline & & After & 0.174 & 138.10 & & \\
\hline & 4 & Before & 0.235 & 186.51 & 4603 & \\
\hline & & After & 0.177 & 140.48 & 10.00 & \\
\hline & 5 & Before & 0.236 & 187.30 & 4762 & \\
\hline & & After & 0.176 & 139.68 & & \\
\hline & 6 & Before & 0.223 & 176.98 & 4286 & \\
\hline & & After & 0.169 & 134.13 & $T 2.00$ & \\
\hline
\end{tabular}




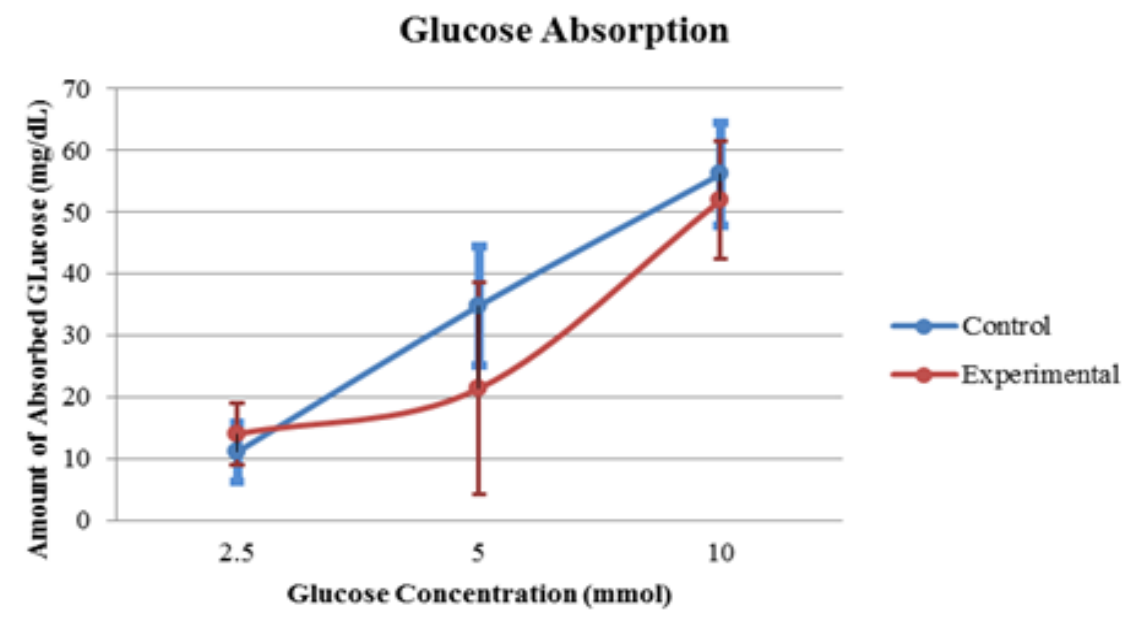

Figure 2 Glucose Concentration

minutes. The absorbance data were analyzed with the spectrophotometer in $505 \mathrm{~nm}$ wave length.

Next, the data were calculated and analyzed using independent t-test to compare data with and without Morinda citrifolia leaf extract solution, with significant values of $\mathrm{p}<0.05$.

On the other side, kinetics calculation was not using computerized tools or applications. This study used a millimeter block paper to draw a graph of Lineweaver-Burk with 1/S $(\mathrm{S}=$ concentration of glucose $)$ on axis and $1 / \mathrm{V}$ (V=velocity of absorption which was equal to the amount of absorbed glucose). There were 2 lines to be drawn, control (G) and experimental
(M). For the axis, 1 smallest square equals to $0.002 / \mathrm{mmol}$, and the ordinate, 1 smallest square equals to $0.0001 / \mathrm{mg}$. Then we took the point of both intersections with axis and use it as a value of $-1 / \mathrm{Km}$.

\section{Results}

Results from this study showed that in glucose with $2.5 \mathrm{mmol}$ concentration, the addition of Morinda citrifolia leaf extract was not providing much difference in the mean of absorbed glucose. In fact, data of the solution with extract had $2.91 \mathrm{mg} / \mathrm{dL}$ more higher absorbed glucose than the solution without

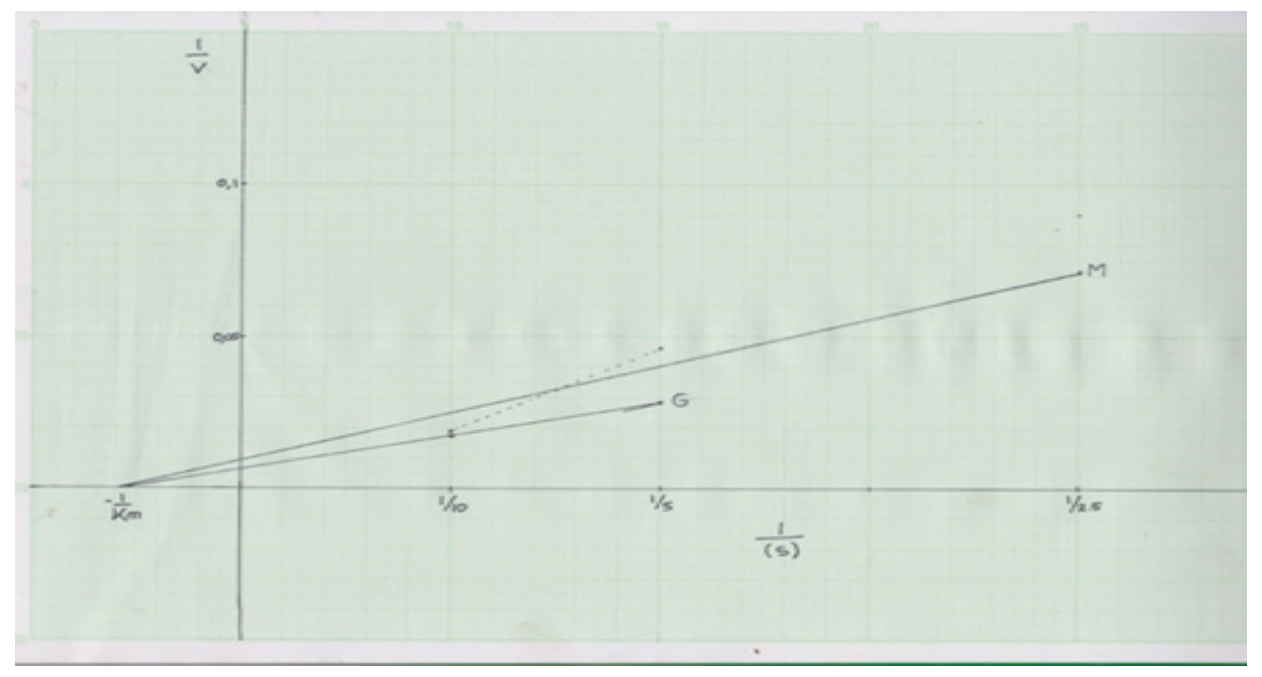

Figure 3 Graph of Lineweaver-Burk ${ }^{9}$ 
extract (Table 1). A difference was found in $5 \mathrm{mmol}$ of glucose concentration. The mean of absorbed glucose in the control group was $14.94 \mathrm{mg} / \mathrm{dL}$ much more than in the group with extract. There was also a difference in $10 \mathrm{mmol}$ glucose concentration with extract, since the mean of absorbed glucose was 4.23 $\mathrm{mg} / \mathrm{dL}$ less than in the control group (Table 2).

The rise of glucose absorption following the increase of glucose concentration showed the red line, which represented glucose with extract, mostly had a position below the blue one, which represented glucose only solution. There was no significant effects of Morinda citrifolia leaf extract in glucose absorption (Figure 2).

Next, we calculated the kinetics of glucose transport with and without Morinda citrifolia leaves which showed that the one without additional extract had value of $-1 / \mathrm{Km}=-0.058$. Therefore, the $\mathrm{Km}=17.24$. The second, which was glucose with extract, had value of -1 / $\mathrm{Km}=-0.06$ and made the $\mathrm{Km}=16.67$ (Figure 3).

\section{Discussions}

Moreover, a statistical test was performed and found there was not any significant results in glucose concentration with p value 0.324 (2.5 $\mathrm{mmol}$ ); 0.091 ( $5 \mathrm{mmol})$; and $0.433(10 \mathrm{mmol}$ ).

Although in two concentrations of glucose showed that there were decreases in glucose absorption,the statistical test gave insignificant results. This may occur with reasons such as the occurrence of a different antihyperglycemic mechanism. A previous study showed Morinda leaves have two antihyperglicemic mechanisms, by increasing the production of insulin and increasing the peripheral utilization of glucose. ${ }^{12}$

There were also limitations in this study. The variety of each rat's ability to absorb glucose should be considered which took part in varies results. In addition, the insulin also took part in glucose absorption from the cell into bloodstream. ${ }^{13}$

It can be concluded that there is no effect of Morinda citrifolia leaf extract on intestine glucose absorption in wistar rats which is shown by statistical test results with $p$ values $>0.05$. On the other hand, the kinetic results show a little difference in $\mathrm{Km}$ values, which mean the inhibitor, is not interfered by the glucose transport in the absorption process. We suspect a non-competitive inhibition of intestine glucose absorption by Morinda citrifolia leaf extract. ${ }^{9}$

We suggest further studies to investigate the effects of Morinda citrifolia leaf extract with higher dosage. Furthermore, a study to develop the kinetic results of glucose transport still needs to be done.

\section{References}

1. Agromedia R. Buku pintar tanaman obat: 431 jenis tanaman penggempur aneka penyakit. Jakarta: Agromedia Pustaka; 2008.

2. Surialaga S, Dhianawaty D, Martiana A. Efek antihiperkolesterol jus buah belimbing wuluh (averhoa bilimbi L.) terhadap mencit galur swiss webster hiperkolesterolemia. Majalah Kedokteran Bandung. 2013;45(2):125-9.

3. Chan-Blanco Y, Vaillant F, Perez AM, Reynes M, Brillouet J-M, Brat P. The noni fruit (Morinda citrifolia L.): a review of agricultural research, nutritional and therapeutic properties. J Food Comp Anal. 2006;19(6):645-54.

4. Wardiny TM, Retnani Y, Sinar TEA. Penampilan puyuh starter yang diberi ekstrak daun mengkudu sebagai antibakteri salmonella thypimurium. Prosiding Seminar Nasional MIPA; 2012. [cited 2016 January 10] Available from: https://ejournal.undiksha.ac.id/index. php/semnasmipa/article/view/2786

5. Castro MA, Angulo C, Brauchi S, Nualart F, Concha, II. Ascorbic acid participates in a general mechanism for concerted glucose transport inhibition and lactate transport stimulation. Pflugers Arch. 2008;457(2):519-28.

6. El-Tantawy W, Hassanin L. Hypoglycemic and hypolipidemic effects of alcoholic extract of Tribulus alatus in streptozotocininduced diabetic rats: a comparative study with T. terrestris (Caltrop). Indian J Exp Biol. 2007;45(9):785-90.

7. Kwon O, Eck P, Chen S, Corpe CP, Lee J-H, Kruhlak M, et al. Inhibition of the intestinal glucose transporter GLUT2 by flavonoids. FASEB J. 2007;21(2):366-77.

8. Soewondo P, Pramono LA. Prevalence, characteristics, and predictors of prediabetes in Indonesia. Med J Indones. 2011;20(4):283-94.

9. Shahib MN. Biologi molekuler medik. Bandung: P.T. Alumni; 2012.

10. Charan J, Kantharia ND. How to calculate sample size in animal studies? J Pharmacol Pharmacother. 2013;4(4):303-6.

11. Festing S, Wilkinson R. The ethics of animal research. EMBO J. 2007;8(6):526-30. 
12. Adeneye A, Agbaje E. Pharmacological evaluation of oral hypoglycemic and antidiabetic effects of fresh leaves ethanol extract of Morinda Lucida Benth. in normal and alloxan-induced diabetic rats. Afr J
Biochem Res. 2008;11(1):65-71.

13. Kellett GL, Brot-Laroche E, Mace OJ, Leturque A. Sugar absorption in the intestine: the role of GLUT2. Annu Rev Nutr. 2008;28:35-54. 